\title{
Modelling hydrodynamics of large lagoons: \\ Insights from the Albemarle-Pamlico Estuarine System
}

\author{
Gregory J. Clunies, Ryan P. Mulligan* \\ Department of Civil Engineering, Queen's University, Kingston, ON, Canada, K7L3N6 \\ David J. Mallinson, J.P. Walsh \\ Department of Geological Sciences, East Carolina University, Greenville, NC, USA, 27858
}

*Corresponding author. Tel.: 613533 6503; fax: 6135332128.

E-mail address: mulligar@queensu.ca (R.P. Mulligan). 


\section{Abstract}

Large estuaries are influenced by winds over adjacent coastal ocean and land areas causing significant spatial variations in water levels, currents and surface waves. In this study we apply a numerical model to simulate hydrodynamics and waves in the Albemarle-Pamlico Estuarine System, a large and shallow back-barrier basin in eastern North Carolina, over a one-month study period (September, 2008) with observations from several storm wind events of differing time scales and directions. Model performance is evaluated for a spatially varying wind field from the North American Regional Reanalysis (NARR) dataset in comparison to spatially uniform forcing from wind observations at offshore, coastal and land-based sites across the region. A spatially uniform wind field from offshore winds observations results in statistically better hydrodynamic simulations of water levels $(\mathrm{R}=0.88)$ in the estuaries than NARR $(\mathrm{R}=0.48)$ after comparison with measurements and indicates the importance of strong marine winds over most of the estuary surface area.

The influence of a prominent bathymetric feature on hydrodynamics in Pamlico Sound is also investigated by numerically removing a $30 \mathrm{~km}$ long and 2-3 $\mathrm{m}$ deep shoal from the model grid and replacing it with an idealized depth of $6 \mathrm{~m}$. The removal of the shoal increases water level setup by $14 \%$ at the estuarine shoreline, decreases current magnitudes by up to $40 \%$ in the shoal region and increases significant wave heights locally by up to $25 \%$ in the sound, indicating the importance of this relict geomorphic feature as a major control on the hydrodynamic response of the system during wind events. The results suggest that increasing the water depth over the shoal can lead to higher storm surges and wave heights with the possibility of increased inundation and erosion of the back-barrier and mainland coastal regions. The complex bathymetry and marine wind influence are critical input conditions for modelling large and shallow lagoonal estuaries like the Albemarle-Pamlico Estuarine System.

\section{Keywords}

storm surge; estuaries; lagoons; wind-driven currents; surface waves; numerical models 


\section{Introduction}

Large lagoonal estuaries are common landforms found along the U.S. Atlantic and Gulf coasts (Nichols, 1989) and along the coasts of most continents. They are important systems that have dynamic geological, biological and chemical processes (Peierls and Paerl, 2010), provide habitat to marine organisms, and have great environmental and economic value (Barbier et al., 2011). Physical processes in estuaries and lagoons are driven by tides, river input, and wind stress, but each system responds differently to these forcing functions due to differences in geomorphology (Kjerfve and Magill, 1989) and the responses can be difficult to determine as they are often under-monitored. North-eastern North Carolina is home to a large system of interconnected estuaries and lagoons collectively called the Albemarle-Pamlico Estuarine System (APES), shown in Figure 1. The lagoonal system is characterized by a mean water depth of $5 \mathrm{~m}$, muddy to sandy sediments (Wells and Kim, 1989), and marine and estuarine water are exchanged through inlets. In the present, Pamlico Sound in connected to the Atlantic Ocean via three Inlets (Oregon Inlet, Hatteras Inlet and Ocracoke Inlet) which are approximately $1.0 \mathrm{~km}$, $2.4 \mathrm{~km}, 2.3 \mathrm{~km}$ wide respectively. The number and width of inlets have a large effect on salinity levels, circulation, and bathymetry of the back-barrier system (Mallinson et al., 2008). The APES is bordered to the east by $260 \mathrm{~km}$ of barrier islands commonly known as the Outer Banks that enclose the low-energy back-barrier environment. The low-lying spits/islands and the mainland coastal plain, less than $4 \mathrm{~m}$ above mean sea level (MSL), are susceptible to storm impacts from waves and storm surges that can cause island inundation and can form new inlets (Mulligan et al., 2015a). The barrier islands serve as a popular location for human activity, making island maintenance and stability a political and economic priority (Riggs et al., 2011).

Wind is the dominant mechanism that drives changes in water levels and currents in the APES (Luettich et al., 2002). Wind speeds can be very high especially at the coast (e.g. near Cape Hatteras) with strong gradients in wind speed and sea-level atmospheric pressure often associated with coastal fronts (Appel et al, 2005). In previous studies, numerical models have been used to simulate hydrodynamics of 
the APES. These models include: ADCIRC (Advanced CIRCulation) to investigate seiching (Luettich et al., 2002) and oyster larval transport (Haase et al., 2012); the Princeton Ocean Model (POM) to estimate density driven circulation (Xie and Pietrafesa, 1999) and storm surge and inundation (Peng et al., 2004); the Regional Ocean Modeling System (ROMS) to compute circulation and salt transport (Jia and Li, 2012); and Delft3D to investigate hurricane-generated waves and storm surge (Mulligan et al., 2015a), estuarine circulation and dissolved organic carbon transport (Brown et al., 2014), and sediment transport (Mulligan et al. 2015b). Spatially uniform wind fields have been used in numerical models of the APES (e.g., Luettich et al., 2002; Haase et al., 2012) and are typically used for small-scale (i.e., single beach) to medium-scale (i.e., lakes, estuaries, bays) numerical models. Spatially varying wind fields have been used to model cyclonic storms (e.g., Mulligan et al., 2015a; Brown et al., 2014) on short time scales. Spatial variability in the wind field and its effect on circulation have been shown to be important in lakes (Podsetchine and Schernewski, 1999), due to wind sheltering effects of surrounding shorelines and vegetation, and can drastically change circulation patterns.

The objective of this paper is to evaluate the effectiveness of a spatially varying wind field in this large, near-ocean system, and the influence of a long sand shoal on the hydrodynamics. Observations from a time period with many sensors deployed across the estuarine system are presented and coupled numerical models called Delft3D (Lesser et al., 2004) and SWAN (Booij et al., 1999) are used to simulate the hydrodynamics and surface waves. Model results are compared to observations over a one-month period with several storm events of different time scales and directions, yielding insight into the influence of wind forcing and bathymetric control on the hydrodynamics.

\section{Observations}

Observation stations for winds, water levels, currents, and surface waves for the study period in September, 2008, are shown in Figure 1. This time period was selected based on the availability of data 
across the region and the occurrence of two storm events that had similar wind speeds from opposing wind directions.

\subsection{Winds}

Hourly wind observations at three sites distributed geographically across the region (Figure 1) were selected for statistical analysis. These include: 1) the US Army Corps of Engineers Field Research Facility (FRF) anemometer, which is positioned on the end of an ocean research pier $0.5 \mathrm{~km}$ from the shoreline (denoted FO); 2) the US National Data Buoy Center (NDBC) Station 41025 buoy at Diamond Shoals (DS) located 26 km offshore of Cape Hatteras; and 3) the land-based Marine Corps Air Station at Cherry Point $(\mathrm{CP})$ that is $24 \mathrm{~km}$ inland from the coast. The marine wind anemometer at FO sampled wind speed and direction at $2 \mathrm{~Hz}$, with resolution of $0.1 \mathrm{~ms}^{-1}$ and $1.0^{\circ}$ at $8.6 \mathrm{~m}$ elevation. The anemometers at DS and CP measured wind at $1.71 \mathrm{~Hz}$ with resolution of $0.1 \mathrm{~ms}^{-1}$ and $1.0^{\circ}$ at $5.0 \mathrm{~m}$ and $9.0 \mathrm{~m}$ elevations respectively. All wind observations were adjusted to $10 \mathrm{~m}$ elevation assuming a logarithmic surface boundary layer (Mulligan et al., 2011). The wind speed and direction at the three stations are shown in Figure 2, indicating that winds at the ocean-based stations (FO, DS) are very similar compared to the weaker conditions at the land-based station (CP). Two storms occurred during the month: a short duration event on Yearday 250 with southerly wind and a longer duration event on Yearday 260269 with northerly wind (note "Yearday" indicates the day in 2008, where January 1 equals Yearday 1).

A spatially varying wind field was obtained from the North American Regional Reanalysis (NARR) dataset. NARR is a long-term, dynamically consistent, high-resolution, high-frequency atmospheric and land surface hydrology dataset with a domain that covers North America at a horizontal resolution of $32 \mathrm{~km}$ (Mesinger et al., 2006). It covers the period from 1979 to present at a temporal resolution of 3 hours. NARR uses a sequence of steps in which the analysis from a previous time step is used as a first guess for the next time step and supplemented by inputs from the three-dimensional data assimilation (Mesinger et al., 2006) to determine atmospheric variables over 45 vertical layers. This detailed and important atmospheric data is useful in many environmental, climatological and 
hydrotechincal applications. In the present study we apply the results of the NARR dataset as input to a coupled hydrodynamic and wave model, and analyze the results in detail to determine the best agreement by statistical comparison with field observations. The U (oriented along lines of latitude) and V (oriented along lines of longitude) wind velocity components and atmospheric pressure (P) at an elevation of $10 \mathrm{~m}$ were obtained for a rectangular sub-domain of the NARR dataset covering eastern North Carolina. Two

time steps of the NARR wind field are shown in Figure 3 for Yearday 249.625 and 250.375, illustrating complex spatial structure over the APES with strongest winds typically over the ocean and eastern part of Pamlico Sound near Cape Hatteras.

To investigate the suitability of using spatially varying wind fields for modeling and to identify spatial variability in winds across the region, correlation coefficients were calculated between the time series observations at each station (FO, DS, CP) and the NARR output at each station. The observed wind components and corresponding NARR output from the appropriate grid cell at each station are shown in Figure 4. The correlation coefficients are listed in Table 1, and overall the NARR winds have reasonable agreement with observed winds with an average correlation coefficient over all three sites of 0.88 over the 30-day period. NARR had high correlation with observations at all stations compared to the lower correlation between observations at individual stations. Winds at CP had low correlation with winds at FO and DS, suggesting the influence of land on winds at this site. The ability of NARR to accurately represent the wind field at three different locations in the region suggests that the spatially varying wind field is representative of winds across the region and could provide the best wind forcing for the hydrodynamic model.

\subsection{Water Levels, Waves and Currents}

Water level, wave and current observations over the study period are shown in Figure 5 with the winds at DS (Figure 5a), and the two storm periods from different directions are notable. Hourly water levels in the ocean were obtained from NDBC station BFTN7 at Beaufort (BF) and at FO (Figure 5b). 
Water level observations (relative to MSL) and current velocity measurements were made using Nortek Vectors; each were deployed $1.0 \mathrm{~m}$ above the seabed at P1 (3.4 m mean water depth), P2 (5.0 m mean water depth), and AS (5.3 m mean water depth) stations (Figure 5c,d). The Vectors burst sampled for 256 seconds every hour at a rate of $8 \mathrm{~Hz}$. Hourly water levels in the sounds were also obtained from pressure gauges at the USGS station 02084472 (P0) at Washington (Figure 5c), and NDBC station ORIN7 at Oregon Inlet Marina (OI) and the US Army Corps of Engineers Field Research Facility in Currituck Sound (CS) shown in Figure 5d. Surface waves were also observed using the Vectors, and due to attenuation of high frequency waves with depth, wave observations are only reliable when the peak wave period $\left(\mathrm{T}_{\mathrm{p}}\right)$ is greater than $2.8 \mathrm{~s}$.

The two major storm surge events in September, 2008 (hereafter referred to as Storm A and Storm B), were defined as prolonged periods when the wind speed exceeded $10 \mathrm{~ms}^{-1}$ (Figure 5a). These storms were selected for comparison since they have the same peak wind peak of $18 \mathrm{~ms}^{-1}$, but are very different in wind direction and storm duration, and cause a very difference storm surge response in the estuaries. Storm A had a rapid increase in wind speed on Yearday 250 with winds from the southeast that shifted to the southwest with a peak of $18 \mathrm{~ms}^{-1}$. The winds during Storm A changed the mean water levels across the system, increasing water levels at stations in the southwestern region (P0, P1) starting on Yearday 249 (Figure 5c). After Yearday 250, the winds rapidly shifted and decreased in strength (Figure 5a), and this resulted in a rapid reduction in water levels at the southwestern stations and a peak in the current magnitudes up to $0.20 \mathrm{~ms}^{-1}$ at P1 and up to $0.35 \mathrm{~ms}^{-1}$ at $\mathrm{P} 2$ (Figure 5e) and an increase in water levels at northern stations (Figure 5d). Water levels at stations in narrow sub-estuaries (P0, P1, CS) exhibited the highest storm surge. Storm B was a long duration wind event that gradually increased in speed from 10 to $18 \mathrm{~ms}^{-1}$ over a ten-day period (Yearday 260-269) with a wind direction that was fairly consistent from the north to northeast. This resulted in water level set-up at southern stations (Figure 5c) and set-down at northern stations (Figure 5d) which was lowest at CS. Water levels at P2 were $0.30 \mathrm{~m}$ higher during Storm B than Storm A, indicating that Pamlico Sound requires a longer duration storm to generate higher water level set-up in comparison to the P0 and P1 sites in the narrow Tar-Pamlico River- 
Estuary (TPRE). Maximum current magnitudes at P1, P2, and AS were weaker (less than $0.15 \mathrm{~ms}^{-1}$ ) during Storm B due to the slow changes in wind speed compared to Storm A.

A consistently amplified water level response, in both the observations and the model predictions, occurs throughout the study period at the head of the TPRE (P0) in comparison to the mouth (P2). This suggests that it is being forced close to its resonant frequency, and the natural t period of an idealized tidal estuary with a single node at the estuary mouth is given by:

$T_{n}=\frac{4 L}{(2 n+1) \sqrt{g h}}$

where $L$ is the estuary length; $g$ is the gravitational constant $\left(9.81 \mathrm{~ms}^{-2}\right) ; h$ is the estuary depth, and $n=0$ for the first mode of oscillation (Rabinovich, 2009). For $L=65 \mathrm{~km}$ and $h=3.5 \mathrm{~m}$, the natural period of the TPRE is approximately 12 hours and nearly equal to the period of the M2 tidal constituent. Storm A (24 hours of southerly wind over $10 \mathrm{~ms}^{-1}$ ) caused major amplification of the water levels along the length of the sub-estuary due, unlike the minor water level response during Storm B (240 hours of northerly wind over $10 \mathrm{~ms}^{-1}$ ) indicating the importance of wind direction on water levels. The observations demonstrate that tides are measureable and somewhat important in the APES even at great distances from inlets; however, the wind-driven storm surge can result in much higher water levels that those caused by the tides.

\section{Model}

Delft3D is an open-source numerical modeling system consisting of several integrated models that simulate hydrodynamics, transport of water mass properties and tracers, surface wave generation and propagation, sediment transport, morphological changes, and water quality. The model has been applied to different shallow coastal environments such as embayments (Mulligan et al., 2008b), river deltas (Hu et al., 2009), river mouths (Elias et al., 2012), estuaries (Brown et al., 2014) and lakes (McCombs et al., 2014) with considerable success when compared to observations. 


\subsection{Model Description}

The Delft3D model solves the nonlinear shallow-water equations derived from the Reynolds averaged Navier Stokes equation for incompressible free surface flow. The model can be run in twodimensional (2D) mode or in three-dimensional (3D) mode, where topography-following layers define the vertical dimension. The governing equations for horizontal flow in the $x$ and $y$ directions in time $t$ over depth $h$ is described in detail in Lesser et al. (2004), where $u$ and $v$ are the horizontal velocity components and $w$ is the vertical velocity component. Pressure terms are determined using the Boussinesq approximation where $\eta$ is the water surface elevation from a reference datum, and $g$ is acceleration due to gravity. Horizontal mixing is parameterized using a horizontal eddy viscosity $v_{H}$, and vertical mixing is parameterized using a vertical eddy viscosity $v_{v}$ that is computed using a k- $\varepsilon$ turbulence-closure scheme (Lesser et al., 2004). $M_{x}$ and $M_{y}$ are external sources or sinks of momentum including wind stress, bottom friction, surface wave-driven radiation stress gradients and river discharge, where $\rho$ is the water reference density.

Waves are simulated by the spectral surface wave model SWAN, which accounts for windgeneration, wave-wave interactions and dissipation (Booij et al., 1999). SWAN uses the action balance equation to describe the evolution of the wave field, accounting for refraction over spatially varying bathymetry and current fields. The energy density source terms that control local changes to the wave spectrum include wave growth due to the transfer of wind energy to waves, the nonlinear transfer of wave energy due to wave interactions, the dissipation of wave energy due to whitecapping, the dissipation due to bottom friction and dissipation due to depth-induced wave breaking.

\subsection{Model Setup}

The 3D model was implemented on a spherical model grid with an open boundary along the continental shelf shown in Figure 1, with higher resolution in the narrow sub-estuaries of the APES and lower resolution in the Atlantic Ocean. The vertical grid consisted of 5 uniformly distributed layers, with 
each layer having a thickness equal to $20 \%$ of the local water depth. The average dimensions of the flow model grid were approximately $250 \mathrm{~m}$ with the wave model grid having half the resolution for computational efficiency, resulting in a minimum of 5-6 cells across the tidal inlets and across the terminal ends of the narrow sub-estuaries in the flow grid. Both model domains covered a distance of 220 $\mathrm{km}$ in the east-west direction and $295 \mathrm{~km}$ in the north-south direction. The bathymetry input was developed using a high-resolution digital elevation model of Pamlico Sound (Cross et al., 2005). The model was run in barotropic mode over a 30-day period for the month of September 2008 (Yearday 245275), with computations performed at a time step of $30 \mathrm{~s}$. These simulations each cover period that spans the duration of spring/neap tidal cycle with several major storm event of varying wind speed and direction. The flow model was forced using water levels at the open boundary located along the continental shelf. The open boundary conditions were developed from water level observations at BF and FO (Figure 5b) using linear interpolation along the boundary to account for spatial variability. There are other ways to impose tidal boundary conditions, however this simple method results in accurate simulated water levels (described in Section 4) inside the model domain both close to the ocean near an inlet and far from the ocean at several sites.

Three model runs were conducted using the same water level boundary conditions but with different wind forcing, listed in Table 2. The three wind forcing scenarios include: A) uniform wind field from wind speed and direction observed at FO (Figure 2a); B) uniform wind field from wind speed and direction observed at DS (Figure 2b); and C) spatially varying wind field from NARR. Model runs were started with an initial condition of zero water level (relative to MSL). A Chezy coefficient of $c_{z}=65 \mathrm{~m}^{1 / 2} \mathrm{~s}^{-}$ ${ }^{1}$ was applied uniformly across the model to specify the bottom roughness that acts on the near-bed currents, after sensitivity tests using a range of $c_{z}=46-92 \mathrm{~m}^{1 / 2} \mathrm{~s}^{-1}$ showing no significant change in the simulated water levels. Default settings for horizontal and vertical eddy viscosity of $1 \mathrm{~m}^{2} \mathrm{~s}^{-1}$ and $1 \times 10^{-6}$ $\mathrm{m}^{2} \mathrm{~s}^{-1}$ respectively were used and resulted in good agreement between model results and observations, similar to other studies at similar scales (e.g. Elias et al., 2012) and in the APES (Mulligan et al., 2015a). 
In the wave model, spectral space was defined by 49 logarithmically spaced values with a wide frequency range from $0.05-3.00 \mathrm{~Hz}$ and directions were defined by 36 bins with $10^{\circ}$ spacing. Waves are locally generated by winds and wave growth is described using the parameterization of Komen et al. (1984). Depth-induced breaking in shallow water was defined using the bore-based model of Battjes and Janssen (1978), with the rate of dissipation coefficient of 1.0 and the breaker parameter of 0.73 . Bottom stresses due to wave forces were defined following Fredsøe (1984), and bottom friction was parameterized using the JONSWAP formulation with a coefficient of $0.067 \mathrm{~m}^{2} \mathrm{~s}^{-3}$, which is appropriate for wave conditions in shallow water (Bouws and Komen, 1983). Whitecapping was modeled based on the formulation described by van der Westhuysen et al. (2007) and Mulligan et al. (2008a). The waves are locally generated by winds over the model domain, and there are no wave boundary conditions applied. The Delft3D circulation model and the SWAN wave model communicated every 60 minutes during the simulations and therefore accounted for the effects of wave-current interactions on this time scale.

\section{Model Results and Insights}

The model simulations used temporally varying winds that were either spatially uniform (singlepoint wind observations applied over the entire domain) or spatially variable (from the North American Regional Reanalysis model with data assimilation), and we focus on the model results from the two storm events that drive major water level changes in the estuarine system. The hydrodynamic response of the APES to the three different wind forcing scenarios over the one-month period are evaluated based on correlation coefficient (R) and root-mean square error (RMSE) statistics for water levels, current velocity, significant wave height, and peak wave period.

\subsection{Water Level Validation}

The predicted water levels for each model run (Model A-C) were compared to observed water levels at six stations (P1, P2, OI, CS, AS) in Figure 6. Surprisingly, water levels from the spatially 
uniform wind runs (Model A-B) are generally in much better agreement with observations levels than predictions using the varying wind field (Model C). The spatially varying wind model performance was especially poor during periods of strong winds $(U>10 \mathrm{~m} / \mathrm{s})$, suggesting that NARR may not represent the true wind stress over the large open water areas of the large lagoonal APES where there are no wind observations. NARR forcing resulted in the lowest correlation with observations CS and AS (Figure 6de). For the two model runs that used spatially uniform winds, Model B (DS winds) exhibited the best agreement with data at the six stations with an average correlation of 0.88 and an average root-meansquare error of $0.09 \mathrm{~m}$. Generally water levels were best simulated at sites in Pamlico Sound (P1, P2, OI), with poorer model performance in Albemarle and Currituck Sounds (AS and CS), as indicated by the RMSE and R statistics listed in Table 3. Over the 30-day period the RMSE for Model B is $0.10 \mathrm{~m}$ or less at each site, with a mean RMSE of $0.08 \mathrm{~m}$ across all six sites.

There are unfortunately no velocity observations in or near the inlets during the study period. However, the close agreement in water level elevations between observations and model results at many sites across the estuarine system indicates that discharge through the inlets are correct. Good agreement at a tidally dominated location close to an inlet (OI, Figure 6d) indicates that the ocean water levels were properly simulated using the boundary condition at the continental shelf. Amplification of the water levels along the narrow TPRE sub-estuary was best simulated by Model B, with the semi-diurnal signal diminishing from the head of the TPRE at P0 to the mouth at P2 (Figure 6a-c). The spatially uniform winds from DS (Model B) resulted in the best agreement with observations at all six stations. This suggests that the APES, and likely other large coastal lagoons surrounded by narrow barrier islands, are strongly influenced by marine wind conditions with little to no influence of the narrow barrier island land area on near-surface winds. 


\subsection{Currents and Bathymetric Resolution}

The hydrodynamic response of the APES to marine winds from Storm A (Figure 5a) is characterized by rapid fluctuations in water levels and strong depth-averaged current velocities. The observations and predictions for Storm A are shown where currents were measured (P1, P2, AS) in Figure 7. In the TPRE at P1 for example, the water levels rose to $+0.4 \mathrm{~m}$ and dropped to $-0.3 \mathrm{~m}$ (Figure 7a) resulting in a strong current of $0.2 \mathrm{~ms}^{-1}$ along the channel (Figure 7d) for several hours. In contrast, water level fluctuations were gradual during Storm B (Figure 8) due to the small changes in wind speed (Figure 5a), resulting in weaker currents compared to Storm A. At P1 the water levels rose to $+0.3 \mathrm{~m}$ and remained high for several days (Figure 8a) resulting in a weak current of $<0.1 \mathrm{~ms}^{-1}$ along the channel (Figure 8d). Overall, the water level and current velocity predictions are in better agreement with the observations using spatially uniform winds (Model A-B) compared to the spatially varying winds (Model C) for both wind events. Results from the best model run (Model B, with DS winds) indicate that during Storm A water from Pamlico Sound flowed into the TPRE during southeasterly winds (Figure 9a) that produce a storm surge on the west side of Pamlico Sound (Figure 9b). Subsequently, water flowed out from the sub-estuary to the larger sound during southwesterly winds (Figure 9c), which caused a set-down in southern Pamlico Sound (Figure 9d).

In the low energy back-barrier estuarine system, tidal currents are weak (except near inlets) and current speeds are typically less than $0.1 \mathrm{~ms}^{-1}$ during light winds $<10 \mathrm{~ms}^{-1}$ as indicated by the observations and model results before the storm events in Figures 7 and 8. The predicted current magnitude is in general agreement with the observations; however, the direction was not consistent with observations as indicated by the velocity components. This is attributed to the relatively coarse grid which was unable to resolve flow patterns in the narrow TPRE sub-estuary. Although the model did not simulate the exact currents in the APES, good agreement with observed water levels suggests that the large-scale hydrodynamics are well predicted by Model B (Table 3, Figure 6). Finer resolution model grids, validated with detailed observations at higher spatial resolution, could be used in future modeling studies. 


\subsection{Estuarine Surface Waves}

Unlike ocean beaches with potentially large waves and strong longshore currents, waves and associated wave-driven currents in the estuarine environment are much weaker and cover smaller-scales compared to flows driven by tides and wind-driven storm surges. Coupling of the wave and hydrodynamic models is important, however, in simulating the storm surge to obtain the correct time- and spatially-varying water depth in the shallow APES to compute wave properties accurately. To investigate the importance of waves on the total circulation, a simulation with wind, tidal and river forcing (without waves) was performed and compared to the case with wave forcing included. The results indicate that the wave-driven circulation is significantly less than the wind-driven circulation, due the relatively small waves and gentle estuarine slopes that cause very low radiation stress gradients. Although the waves are important in causing erosion of fine sediments on estuarine shorelines (Eulie et al., 2016), they have a minimal contribution to circulation in this system, the model is used to simulate the total circulation from wind, wave, tidal and river flow forcing.

The significant wave height $\left(\mathrm{H}_{\mathrm{s}}\right)$ and peak period $\left(\mathrm{T}_{\mathrm{p}}\right)$ observed at AS are compared to the three model runs in Figure 10. At this site in Albemarle Sound, Model A had the best correlation with observations (R $=0.82$ ) and captured all major fluctuations in wave parameters while Models B-C had lower correlation $(\mathrm{R}=0.73,0.76$ respectively). Strong performance is attributed to the close distance between AS and the wind station at FO (Model A). Model A predicted the significant wave height at AS during the storm events, with RMSE $<0.04 \mathrm{~m}$ for $\mathrm{H}_{\mathrm{s}}$ up to $1.2 \mathrm{~m}$ during Storm A and RMSE $0.16 \mathrm{~m}$ for $\mathrm{H}_{\mathrm{s}}$ up to $1.3 \mathrm{~m}$ during Storm B. Models A and B had similar results in predicting $\mathrm{T}_{\mathrm{p}}$ compared to observations with RMSE of 0.57 and 0.61 seconds, respectively, over both storms. $T_{p}$ was especially well predicted during Storm B by both models, likely due to the long storm duration resulting in $T_{p}>3 s$ for several days. On average, both models $\mathrm{A}$ and $\mathrm{B}$ under-predicted $\mathrm{T}_{\mathrm{p}}$ by approximately $11 \%$, and Model $\mathrm{C}$ under-predicted $\mathrm{T}_{\mathrm{p}}$ by $50 \%$. Although Storm A and $\mathrm{B}$ had similar maximum wind speeds $\left(18 \mathrm{~ms}^{-1}\right)$, the different directions 
(SW-SE for Storm A; N-NE for Storm B) as well as the different storm duration (1 day for Storm A; 10 days for Storm B) resulted in different wave heights and current velocities at the peak of each storm (Figure 11). The longer storm duration of Storm B results in a fully developed wind-generated wave field in Pamlico Sound (Figure 11b), with significant wave heights up to $1.7 \mathrm{~m}$. Estimation of the wind forcing conditions is important for correct prediction of the surface waves, and the DS winds (Model A) resulted in the best agreement with wave observations indicating the strong influence of marine winds over the APES.

\section{Influence of a Shoal on Hydrodynamics}

The geomorphology of lagoonal systems plays a key role in how it responds to winds and tides. In Pamlico Sound, the largest bathymetric feature is a long and shallow sand ridge called Bluff Shoal. This stable shoal is the modern bathymetric expression of an inter-stream divide between the paleo Neuse River Valley and the paleo Pamlico Creek Valley which incised during the late Pleistocene (Mallinson et al., 2010; Zaremba et al., 2016). It is $30 \mathrm{~km}$ long and 2-3 m deep, oriented north-south across the estuary, and divides Pamlico Sound into two distinct basins (Wells and Kim, 1989) shown in Figure 1.

We hypothesize that this shoal has an important effect on the wave height and flow during storms. The results here reveal its significance, as it is resolved in the model grid and it induces depth-limited breaking across the lagoon. The reduced wave height over the shoal at the maximum wind conditions during each storm event is shown in Figure 11a,b, and this shallow region also influences mean currents (Figure 11c,d). The rapid water level changes during Storm A drive strong northward flows up to 0.45 $\mathrm{ms}^{-1}$ over Bluff Shoal, while the gradual changes in wind speed during Storm B cause storm surge that drives weaker southward flows up to $0.20 \mathrm{~ms}^{-1}$ over the shoal in central Pamlico Sound.

To investigate a major change in the morphology of the basin, we further examine the model results near Bluff Shoal in Pamlico Sound. The influence of this shallow feature on hydrodynamics in the estuarine system were evaluated by numerically removing it from the bathymetric grid (shoal was 
deepened to $6 \mathrm{~m}$ ) and comparing to the model results with the existing shoal bathymetry (using spatially uniform winds from DS for both cases). This is a simple yet effective way to examine the influence of a bathymetric feature under selected conditions. The results indicate that the shoal acts as a partial barrier to storm hydrodynamics in Pamlico Sound (Figure 12). This feature separates the Pamlico into two basins resulting in water level set-up over the shallowest part of the shoal and causes a water level difference of $0.05 \mathrm{~m}$ (at $35 \mathrm{~km}$ in Figure 12b) across the shoal during Storm A. After removal of Bluff Shoal, water level set-up is continuous across the basin with a higher maximum storm surge of approximately $0.03 \mathrm{~m}$ (14\%) at the northern shoreline of Pamlico Sound. Under more extreme wind conditions (e.g. wind speed over $20 \mathrm{~ms}^{-1}$ ) an even greater water level set-up is expected to occur. Predicted current magnitudes decreased from a maximum of $0.5 \mathrm{~ms}^{-1}$ to $0.3 \mathrm{~ms}^{-1}$ after removal of the shoal (Figure 12c; Figure 13). According to the fluid continuity equation, deeper bathymetry should result in slower depth-averaged flow over a larger water column. The vertically integrated flux (product of current magnitude and depth, $|u| h)$ along the section is shown in Figure 12d. The differences before and after removal of the shoal indicates that the vertically integrated fluxes vary over this region and highlights the impact of the shoal on the hydrodynamic circulation. Significant wave heights locally increase by $25 \%$ after removal of the shoal compared to the actual bathymetry where depth-induced breaking over the shoal restricts wave growth in central Pamlico Sound and waves are depth-limited (Figure 12e; Figure 13). The overall effect of removing the shoal is pronounced but localized for both the mean current speed and the significant wave height. The presence of the shoal forces convective acceleration of the flow, thus the absence of it causes weaker currents over a larger depth, and there is a minimal change in flow direction (Figure 13c,d) along the estuary. This highlight the importance of this feature in controlling the overall hydrodynamic response of the large lagoon.

Relative sea-level rise for $\mathrm{NC}$ has been estimated to be 3.4-4.3 $\mathrm{mm} \mathrm{y}^{-1}$ (Kemp et al., 2009). With continuous and potentially accelerating sea-level rise (Kopp et al., 2015), the Outer Banks and the Albemarle-Pamlico Estuarine System are at risk of morphologic changes that could significantly change the hydrodynamics in the back-barrier environment (e.g. inlet opening, Mulligan et al., 2015a). The model 
results here indicate that future changes to major bathymetric features will notably influence the hydrodynamic response of the system. Bluff Shoal moderates the wave height, and creates a region of higher current velocity as water flows over the shoal in response to storm surge driven by wind. Reducing the depth of the shoal results in higher water levels along the mainland estuarine shoreline. Analogous to removing the shoal, an increase in water depth due to sea-level rise in the future could also result in increased storm surge and inundation along the mainland coast and along the back-barrier side of the Outer Banks. Previous work (e.g. Eulie et al., 2013) has demonstrated substantial erosion around the system and the combination of increased storm surge and higher wave energy due to potential deepening of the APES suggests that erosion rates will increase.

\section{Summary and Conclusions}

A coupled numerical circulation (Delft3D) and wave (SWAN) model was used with different wind forcing conditions for a 1-month long period to assess the hydrodynamic response of the AlbemarlePamlico Estuarine System (APES). The study period (September 2008) consisted of two major storm events with different wind directions and storm durations, but with the same maximum wind velocities of approximately $18 \mathrm{~ms}^{-1}$. Model results using a spatially varying wind field from the North-American Regional Reanalysis (NARR) at $32 \mathrm{~km}$ resolution was compared to model results to spatially uniform wind fields developed from observations at the US Army Corps of Engineers Field Research Facility (FO) and the National Data Buoy Center station at Diamond Shoals (DS). It was hypothesized that spatial variability in the wind field would lead to better model performance; however model results indicate that the stronger winds observed at DS result in statistically better hydrodynamic simulations of the estuaries after comparison with observations, indicating the importance of strong marine winds over the estuarine surface area. Simulated water levels were in best agreement with data when spatially uniform wind forcing from DS was used, with an average correlation coefficient of 0.88 and an average root-meansquare error of $0.09 \mathrm{~m}$ across all observation stations. Therefore the most representative winds were those 
from offshore marine wind observations closest to Pamlico Sound, the largest water body in the estuarine system which has a large open water area close to the ocean and separated only by a narrow and lowlying barrier island. The model results indicate that water levels across the APES are strongly dependent on wind speed and direction, and the water level response can be amplified along the length of narrow sub-estuaries.

The hydrodynamic response of a large lagoon to a major change in bathymetry was assessed by numerically removing long and shallow shoal from Pamlico Sound, a simple yet effective way to examine the influence of a sand shoal under selected conditions. The removal of Bluff Shoal increased water levels by $14 \%$ at the estuarine shoreline, decreased current magnitudes by to $40 \%$ over the shoal region and increased significant wave heights locally by $25 \%$ in the sound. These results indicate the importance of this relict geomorphic feature on the hydrodynamic response of Pamlico Sound. Given the possibility of future sea-level rise, the results suggest that increasing the water depth over the shoal will lead to higher storm surge and wave height in Pamlico Sound that could lead to inundation and erosion of the backbarrier and mainland regions. Further research could extend the present study to modelling the hydrodynamic responses to system-wide geomorphic changes such as variations in barrier island segmentation, sea-level rise, and estuarine bathymetry interpreted from the past geologic record to understand the evolution of the Albemarle-Pamlico Estuarine System.

\section{Acknowledgements}

This work was funded by the U.S. National Science Foundation under grant number OCE-1130843. We thank D. Reide Corbett and Devon Eulie at ECU for providing data, and Steve Culver, Edu Leorri and Sid Mitra at ECU as part of the Coastal Hydrodynamics and Natural Geologic Evolution (CHaNGE) project.

\section{References}

Appel, K.W., Riordan, A.J., and Holley, T.A. (2005). “An objective climatology of Carolina coastal fronts", Wea. Forecasting, 20, 439-455. 
Barbier, E.B., Hacker, S.D., Kennedy, C., Koch, E.W., Stier, A.C., and Silliman, B.R., (2011). "The value of estuarine and coastal ecosystem services". Ecological Monographs, 81, 169-193.

Battjes, J., and Janssen, J. (1978). "Energy loss and set-up due to breaking of random waves", Proceedings 16th International Conference Coastal Engineering, ASCE, 569-587.

Booij, N., Ris, R.C., and Holthuijsen, L.H. (1999). "A third-generation wave model for coastal regions: 1. Model description and validation”, Journal of Geophysical Research, 104(C4), 7649-7666.

Bouws, E., and Komen, G. (1983). "On the balance between growth and dissipation in an extreme depthlimited wind-sea in the southern North Sea", Journal of Physical Oceanography, 13, 1653-1658.

Brown, M.M., Mulligan, R.P., and Miller, R.L. (2014). "Modeling the transport of freshwater and dissolved organic carbon in the Neuse River Estuary, NC, USA following Hurricane Irene (2011)", Estuarine, Coastal and Shelf Science, 139, 148-158.

Cross, V., Bratton, J., Bergeron, E., Meunier, J., Crusius, J., and Koopmans, D. (2005). "Continuous resistivity profiling data from the upper Neuse River Estuary, North Carolina, 2004-2005." USGS Open-File Rep. 2005-1306, Reston, VA.

Elias, E. P. L., Gelfenbaum, G. and Van der Westhuysen, A.J. (2012). "Validation of a coupled waveflow model in a high-energy setting: The mouth of the Columbia River", Journal of Geophysical Research, 117, C09011, doi:10.1029/2012JC008105.

Eulie, D.O., Walsh J.P., and Corbett, D.R., (2013). "High-resolution analysis of shoreline change and application of balloon-based aerial photography, Albemarle-Pamlico Estuarine System, North Carolina, USA", Limnol. Oceanogr. Methods, 11, 151-160.

Eulie, D.O., Walsh, J.P., Corbett, D.R., and Mulligan, R.P. (2016). "Temporal and Spatial Dynamics of Estuarine Shoreline Change in the Albemarle-Pamlico Estuarine System, North Carolina, USA". Estuaries and Coasts, 1-17.

Fredsøe, J. (1984). "Turbulent boundary layer in wave-current motion", Journal of Hydraulic Engineering, 110(8), 1103-1120.

Hu, K., Ding, P., Wang, Z., and Yang, S. (2009). “A 2D/3D hydrodynamic and sediment transport model for the Yangtze Estuary, China”, Journal of Marine Systems, 77(1-2), 114-136.

Jia, P., and Li, M. (2012). "Circulation dynamics and salt balance in a lagoonal estuary", Journal of Geophysical Research, 117(C1), C01003.

Kemp, A. C., Horton, B. P., Culver, S. J., Corbett, D. R., van de Plassche, O., Gehrels, W. R., Douglas, B. C., and Parnell, a. C. (2009). "Timing and magnitude of recent accelerated sea-level rise (North Carolina, United States)", Geology, 37(11), 1035-1038.

Kjerfve, B., and Magill, K. E. (1989). "Geographic and hydrodynamic characteristics of shallow coastal lagoons”. Marine Geology, 88(3), 187-199. 
Komen, G., Hasselmann, S. and Hasselmann, K., 1984. "On the existence of a fully developed wind-sea spectrum.” Journal of Physical Oceanography 14: 1271-1285.

Kopp, R.E., Horton, B.P., Kemp, A.C., Tebaldi, C., 2015. Past and future sea-level rise along the coast of North Carolina, USA. Climatic Change DOI 10.1007/s10584-015-1451-x.

Lesser, G.R., Roelvink, J.A., van Kester, J.A.T.M., and Stelling, G.S. (2004). "Development and validation of a three-dimensional morphological model", Coastal Engineering, 51(8-9), 883-915.

Luettich Jr, R.A., Carr, S.D., Reynolds-Fleming, J.V, Fulcher, C.W., and McNinch, J.E. (2002). "Semidiurnal seiching in a shallow, micro-tidal lagoonal estuary", Continental Shelf Research, 22(11-13), $1669-1681$.

Mallinson, D.J., Culver, S.J., Riggs, S.R., Walsh, J.P., Ames, D., and Smith, C.W. (2008). Past, Present and Future Inlets of the Outer Banks Barrier Islands, North Carolina. Department of Geological Sciences East Carolina University, Greenville, NC. 22pp.

Mallinson, D.J., Smith, C.W., Culver, S.J., Riggs, S.R., and Ames, D. (2010). "Geological characteristics and spatial distribution of paleo-inlet channels beneath the outer banks barrier islands, North Carolina, USA", Estuarine, Coastal and Shelf Science, 88(2), 175-189.

McCombs, M. P., Mulligan, R. P., and Boegman, L. (2014). "Offshore wind farm impacts on surface waves and circulation in Eastern Lake Ontario", Coastal Engineering, 93, 32-39. doi:10.1016/j.coastaleng.2014.08.001.

Mesinger, F., DiMego, G., Kalnay, E., Mitchell, K., Shafran, P. C., Ebisuzaki, W., Jović, D., Woollen, J., Rogers, E., Berbery, E. H., Ek, M. B., Fan, Y., Grumbine, R., Higgins, W., Li, H., Lin, Y., Manikin, G., Parrish, D., and Shi, W. (2006). "North American Regional Reanalysis", Bulletin of the American Meteorological Society, 87(3), 343-360.

Mulligan, R.P., Bowen, A.J., Hay, A.E., van der Westhuysen, A.J., and Battjes, J.A. (2008a). "Whitecapping and wave field evolution in a coastal bay", Journal of Geophysical Research, 113(C03008), 1-16.

Mulligan, R.P., Hay, A.E., and Bowen, A.J. (2008b). "Wave-driven circulation in a coastal bay during the landfall of a hurricane", Journal of Geophysical Research, 113(C05026), 1-10.

Mulligan, R.P., Perrie, W., Toulany, B., Smith, P. Hay, A.E., and Bowen, A.J. (2011). "Performance of nowcast and forecast wave models for Lunenburg Bay, NS". Atmosphere-Ocean, 49(1), doi:10.1080/07055900.2011.558468.

Mulligan, R.P., Walsh, J.P., and Wadman, H.M. (2015a). "Storm Surge and Surface Waves in a Shallow Lagoonal Estuary during the Crossing of a Hurricane", Journal of Waterway, Port, Coastal, and Ocean Engineering, 141(4), A5014001, doi: 0.1061/(ASCE)WW.1943-5460.0000260.

Mulligan, R.P., Mallinson, D., Clunies, G., Zaremba, N., Leorri, E., Culver, S., Mitra, S., and Riggs, S., (2015b). "Sediment dynamics and morphological evolution of a large back-barrier estuary", Proc. Coastal Sediments 2015, doi: 10.1142/9789814689977_0205. 
Nichols, M M., (1989). "Sediment accumulation rates and relative sea-level rise in lagoons." Marine Geology 88(3), 201-219.

Peek, K.M., Mallinson, D.J., Culver, S.J., and Mahan, S.A. (2014). "Holocene Geologic Development of the Cape Hatteras Region, Outer Banks, North Carolina, USA", Journal of Coastal Research, 293(1), 41-58.

Peng, M., Xie, L., and Pietrafesa, L.J. (2004). "A numerical study of storm surge and inundation in the Croatan-Albemarle-Pamlico Estuary System”, Estuarine, Coastal and Shelf Science, 59(1), 121137.

Peierls, B.L., and Paerl, H.W., (2010) "Temperature, organic matter, and the control of bacterioplankton in the Neuse River and Pamlico Sound estuarine system”. Aquat. Microb. Ecol., 60:139-149.

Podsetchine, V., and Schernewski, G. (1999). "The influence of spatial wind inhomogeneity on flow patterns in a small lake", Water Research, 33(15), 3348-3356.

Rabinovich, A.B. (2009). "Seiches and Harbor Oscillations", Handbook of Coastal and Ocean Engineering, Y. C. Kim, ed., World Scientific Publishing, Singapore, 193-236.

Riggs, S.R., Ames, D.V., Culver, S.J., and Mallinson, D.J. (2011). The Battle for North Carolina's Coast: Evolutionary History, Present Crisis, and vision for the Future. University of North Carolina Press.

Wells, J.T., and Kim, S.-Y. (1989). "Sedimentation in the Albemarle-Pamlico lagoonal system: synthesis and hypothesis", Marine Geology, 88, 263-284.

van der Westhuysen, A.J., Zijlema, M., and Battjes, J.A. (2007). "Nonlinear saturation-based whitecapping dissipation in SWAN for deep and shallow water", Coastal Engineering, 54(2), 151170.

Xie, L., and Pietrafesa, J. (1999). "Systemwide Modeling of Wind and Density Driven Circulation in Croatan-Albemarle-Pamlico Estuary System Part I : Model Configuration and Testing”, Journal of Coastal Research, 15(4), 1163-1177.

Zaremba, N., Mallinson, D. J., Leorri, E., Culver, S., Riggs, S., Mulligan, R., Horsman, E., and Mitra, S., 2016. Controls on the stratigraphic framework and paleoenvironmental change within a Holocene estuarine system: Pamlico Sound, North Carolina, USA. Marine Geology, 379, 109-123.

\section{Table Captions}

Table 1. Correlation coefficients $(\mathrm{R})$ between observed wind components $(\mathrm{U}, \mathrm{V})$ at different stations $(\mathrm{FO}$, DS, CP) and the NARR wind field at those sites.

Table 2. Model run names and wind field description. 
Table 3. Correlation coefficients (R) and root-mean-square error (RMSE) between observations and model results for water levels at six stations in the APES.

\section{Figure Captions}

Figure 1. Location of relevant places and features including hydrodynamic observations (white circles) at P0, P1, P2, Oregon Inlet (OI), Currituck Sound (CS), Albemarle Sound (AS), and Beaufort (BF). Wind observations (X's) are indicated at the Field Research Facility Ocean (FO), Diamond Shoals (DS) and Cherry Point (CP). The arrows indicate the three existing inlet locations and the curved dashed line indicates section A-A' across Bluff Shoal in Pamlico Sound. Inset indicates the model open boundaries.

Figure 2. Winds observed at three sites distributed geographically across the region: a) FO; b) DS; c) CP in September, 2008. The thick black line indicates wind speed adjusted to $10 \mathrm{~m}$ elevation and thin grey vectors indicate the wind direction in degrees relative to true north, defined as "blowing to" the x-axis. The vertical dashed lines indicate the times shown in Figure 3.

Figure 3. Spatially varying wind field from NARR over the APES a) Yearday 249.625; b) Yearday 250.375, 2008 (times indicated on Figure 2). Red vectors indicate wind direction with coloured contours indicating wind speed. The black line shows the coastline of NC.

Figure 4. Observed U- (black line) and V-component (grey line) wind velocities at a) FO; b) DS; c) CP adjusted to $10 \mathrm{~m}$ elevation along with corresponding NARR outputs for U- (black dots) and Vcomponent (grey x's) wind velocities at each station.

Figure 5. Observations in September 2008 for: a) wind speed (red line) at $10 \mathrm{~m}$ elevation and direction (grey vectors) at DS, where wind direction is in degrees relative to true north and defined as "blowing to" the X-axis. Dashed black vertical lines indicate the periods of Storm A and Storm $\mathrm{B}$; b) water level boundary conditions at FO and BF; c) water levels at P0, P1, P2; d) water levels at OI, CS, AS; d) current magnitude at P1, P2, AS.

Figure 6. Water level observations and model results at a) P0; b) P1; c) P2; d) OI; e) CS; and f) AS, using three different wind forcing methods: Model A (FO winds), Model B (DS winds), and Model C (NARR winds).

Figure 7. Observations and model results for water levels $(\eta)$ and depth-averaged current components (u, v) at: P1, P2, and AS for Storm A. The dashed lines in a) indicate the times shown in Figure 9.

Figure 8. Observations and model results for water levels $(\eta)$ and depth-averaged current components (u, v) at: P1, P2, and AS for Storm B.

Figure 9. Model results in the APES and eastern Pamlico Sound during Storm A, indicating: a) peak inflowing depth-averaged currents in the TPRE (Yearday 250.375); b) maximum water levels in the TPRE (Yearday 250.500); c) peak outflowing depth-averaged currents in the TPRE (Yearday 250.750); and d) minimum water levels in the TPRE (Yearday 251.000). 
Figure 10. Observed and predicted wave statistics in Albemarle Sound (AS) for: a) significant wave height $\left(\mathrm{H}_{\mathrm{s}}\right)$, and $\left.\mathrm{b}\right)$ peak wave period $\left(\mathrm{T}_{\mathrm{p}}\right)$, for $\mathrm{T}_{\mathrm{p}}>2.8 \mathrm{~s}$.

Figure 11. Model results indicating the: a) significant wave height $\left(\mathrm{H}_{\mathrm{s}}\right)$ for the peak conditions of Storm A; b) $\mathrm{H}_{\mathrm{s}}$ for the peak conditions of Storm B; c) depth-averaged current velocities for the peak conditions of Storm A; and d) depth-averaged current velocities for the peak conditions of Storm B.

Figure 12. Model results along section A-A' in Figure 1 at Yearday 250.625 for the cases with Bluff Shoal included and removed from Pamlico Sound: a) bathymetry; b) water level; c) depthaveraged current magnitude; d) vertically integrated flux; and e) significant wave height.

Figure 13. Model results for correspond to Storm A: a) significant wave height for present day existing bathymetry; b) significant wave height with Bluff Shoal removed; c) depth-averaged current velocity vectors (black) and magnitude contours (coloured) for present day existing bathymetry; and d) with Bluff Shoal removed. 
Table 1.

\begin{tabular}{|c|c|c|c|c|c|c|}
\cline { 2 - 7 } \multicolumn{1}{c|}{} & \multicolumn{2}{c|}{ FO } & \multicolumn{2}{c|}{ DS } & \multicolumn{2}{c|}{ CP } \\
\cline { 2 - 7 } \multicolumn{1}{c|}{} & $\mathbf{U}$ & $\mathbf{V}$ & $\mathbf{U}$ & $\mathbf{V}$ & $\mathbf{U}$ & $\mathbf{V}$ \\
\hline FO & 1 & 1 & 0.74 & 0.87 & 0.64 & 0.88 \\
\hline DS & 0.74 & 0.87 & 1 & 1 & 0.73 & 0.84 \\
\hline CP & 0.64 & 0.88 & 0.73 & 0.84 & 1 & 1 \\
\hline NARR & 0.90 & 0.93 & 0.83 & 0.92 & 0.78 & 0.91 \\
\hline
\end{tabular}

Table 2.

\begin{tabular}{|c|c|}
\hline Model Run Name & Wind Field Description \\
\hline Model A & $\begin{array}{r}\text { Spatially uniform wind field, from observations at the } \\
\text { FRF on the Ocean side (FO) }\end{array}$ \\
\hline Model B & $\begin{array}{c}\text { Spatially uniform wind field, from observations at the } \\
\text { Diamond Shoals Buoy (DS) }\end{array}$ \\
\hline Model C & $\begin{array}{c}\text { Spatially varying wind field, from the North American } \\
\text { Regional Reanalysis (NARR) }\end{array}$ \\
\hline
\end{tabular}

Table 3.

\begin{tabular}{|c|c|c|c|c|}
\cline { 3 - 5 } \multicolumn{1}{c|}{} & Model A & Model B & Model C \\
\hline P0 & $\mathrm{R}$ & 0.75 & 0.84 & 0.71 \\
\hline & RMSE (m) & 0.14 & 0.10 & 0.14 \\
\hline P1 & $\mathrm{R}$ & 0.84 & 0.87 & 0.81 \\
\hline & RMSE (m) & 0.11 & 0.08 & 0.10 \\
\hline P2 & $\mathrm{R}$ & 0.87 & 0.92 & 0.84 \\
\hline & RMSE (m) & 0.09 & 0.06 & 0.09 \\
\hline OI & $\mathrm{R}$ & 0.87 & 0.90 & 0.60 \\
\hline & RMSE (m) & 0.08 & 0.08 & 0.13 \\
\hline CS & $\mathrm{R}$ & 0.89 & 0.93 & 0.18 \\
\hline & RMSE (m) & 0.13 & 0.10 & 0.28 \\
\hline AS & $\mathrm{R}$ & 0.48 & 0.80 & -0.25 \\
\hline & RMSE (m) & 0.14 & 0.09 & 0.21 \\
\hline
\end{tabular}




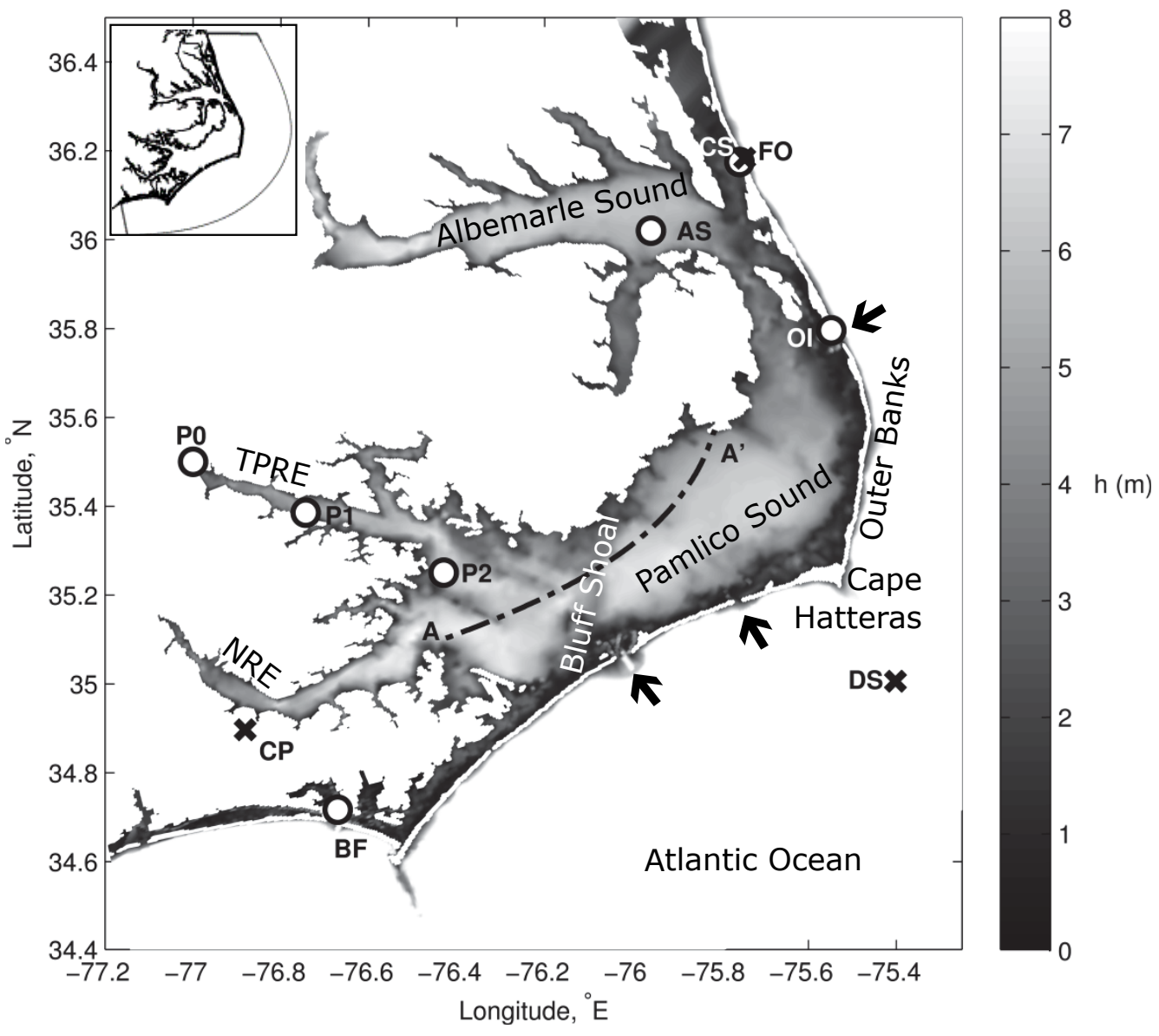



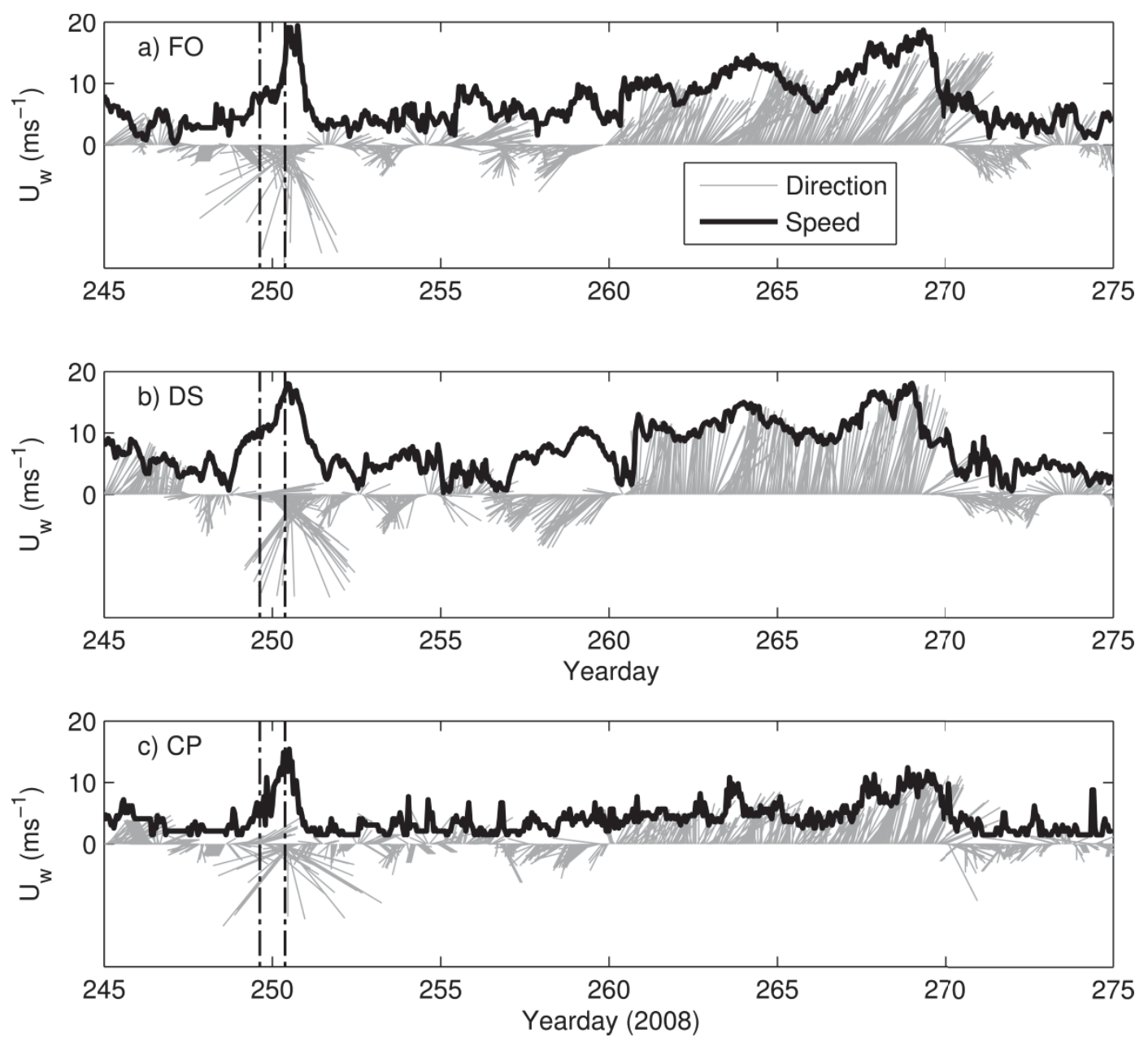

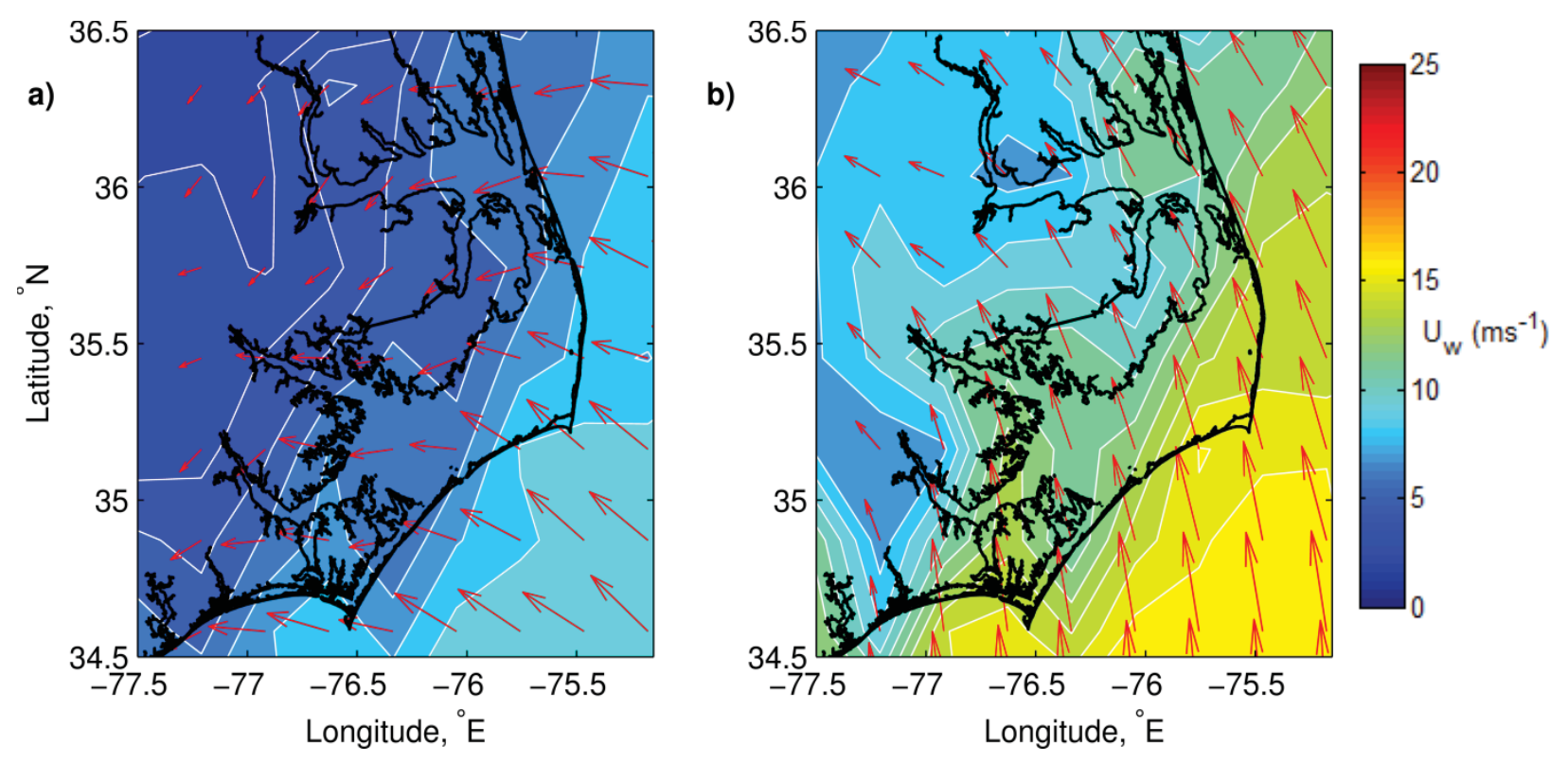

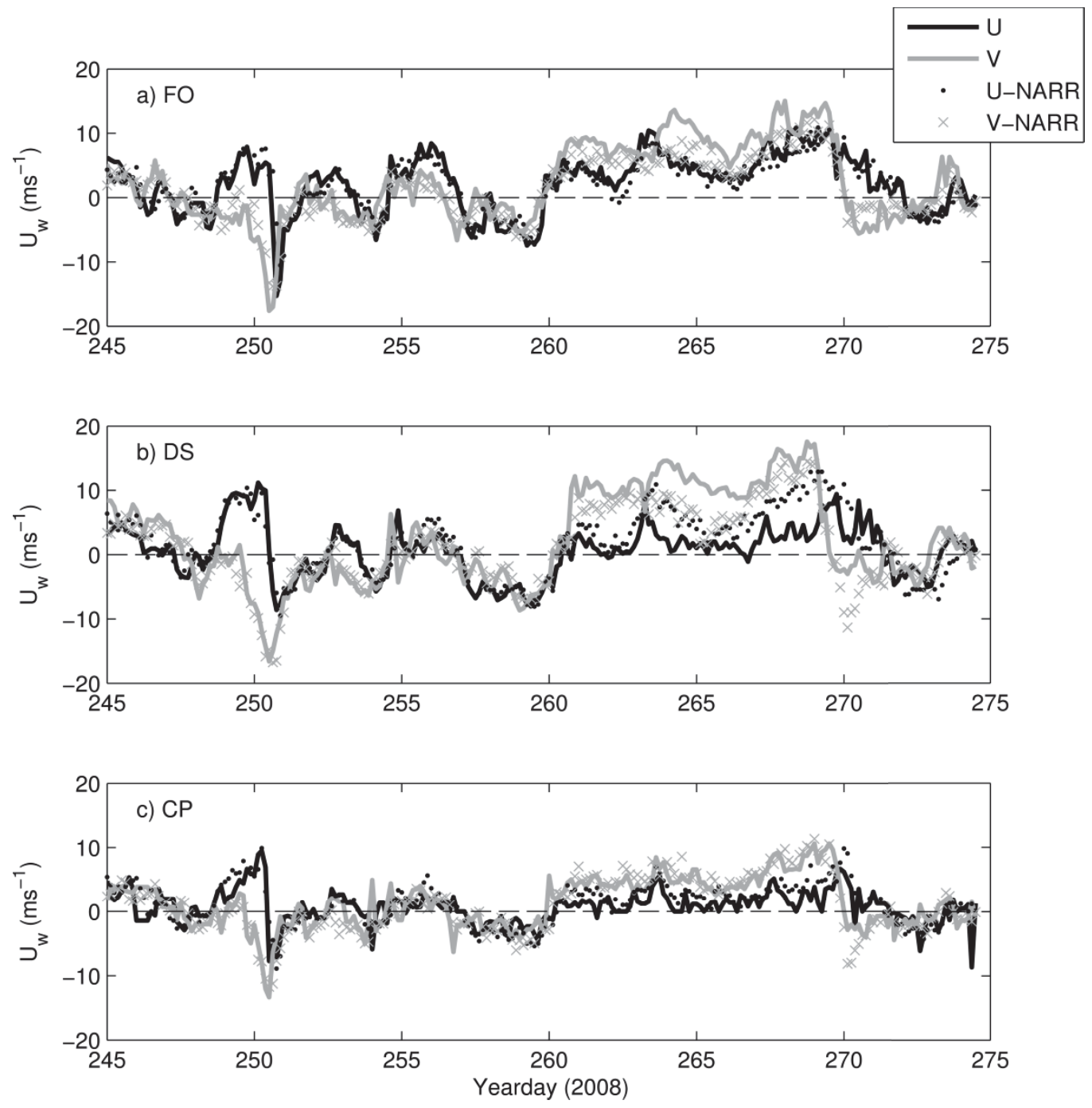

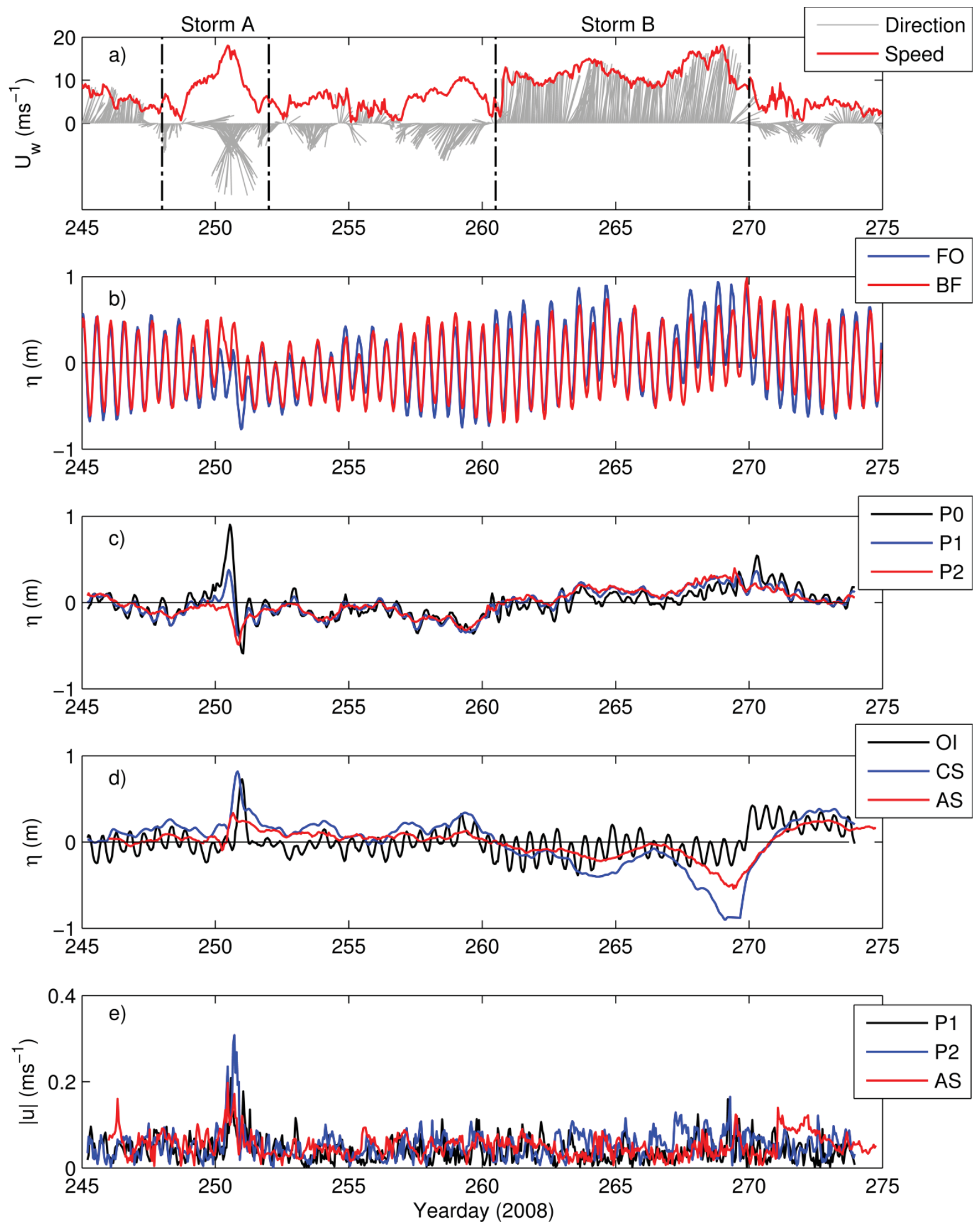

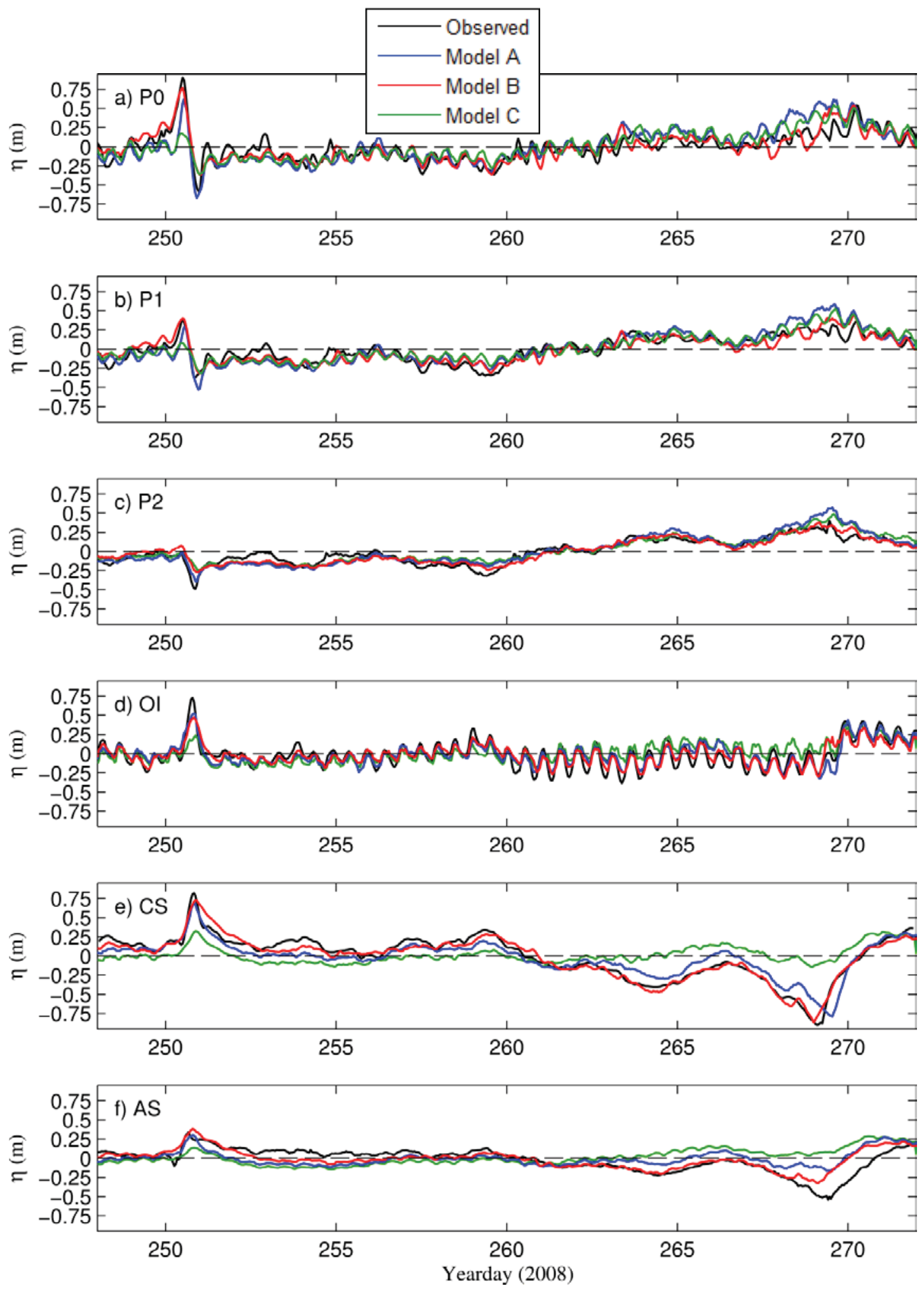

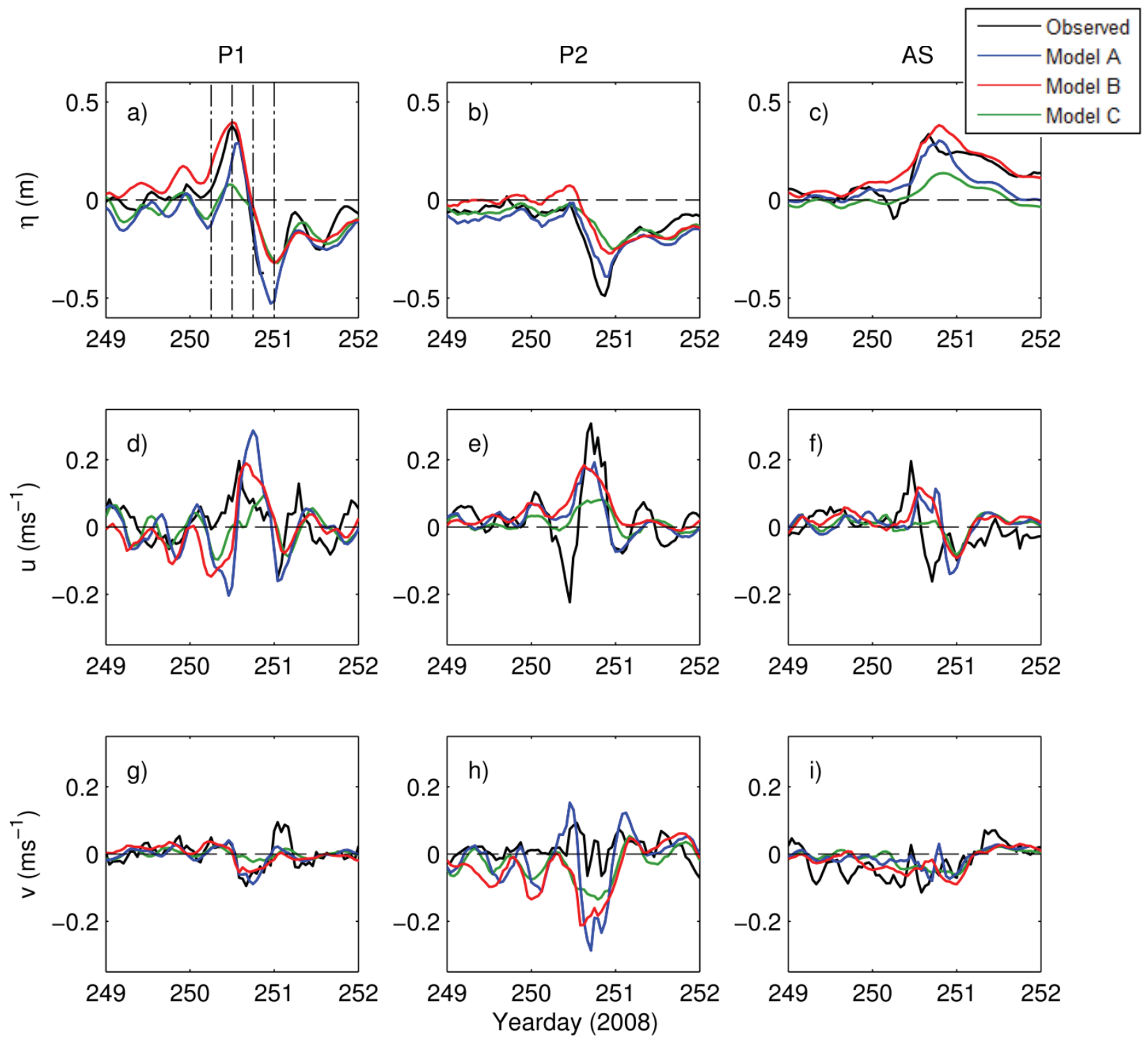

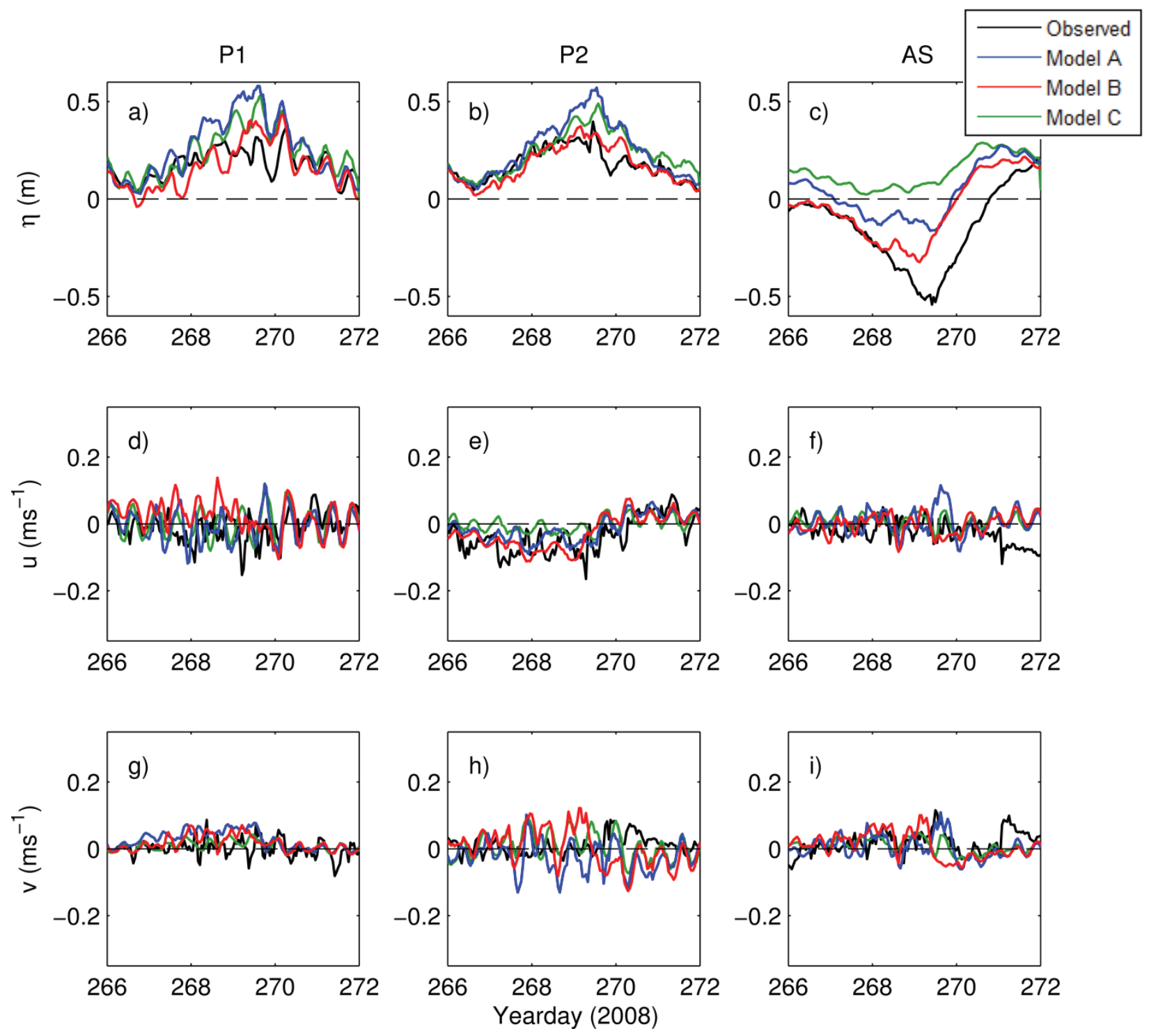

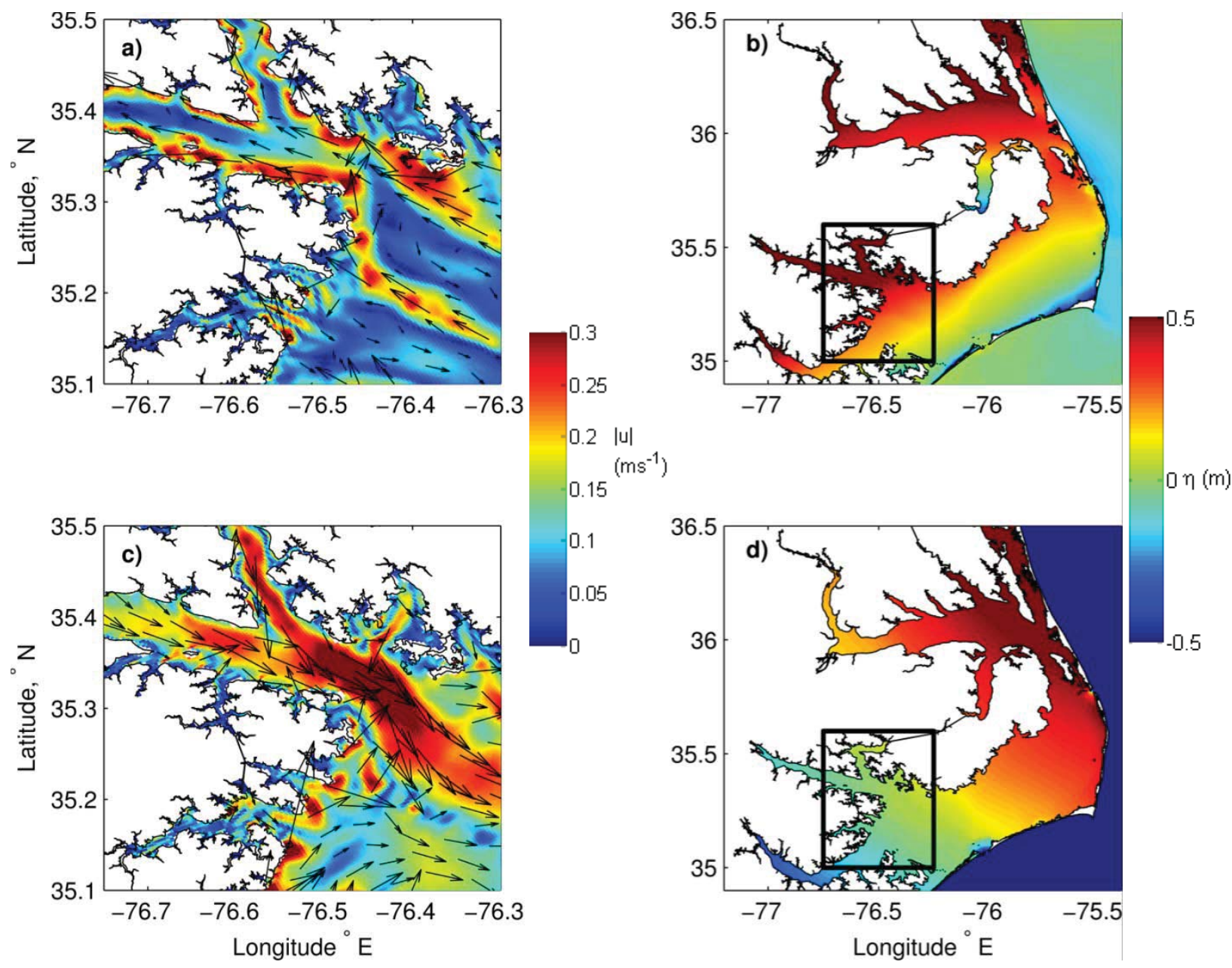

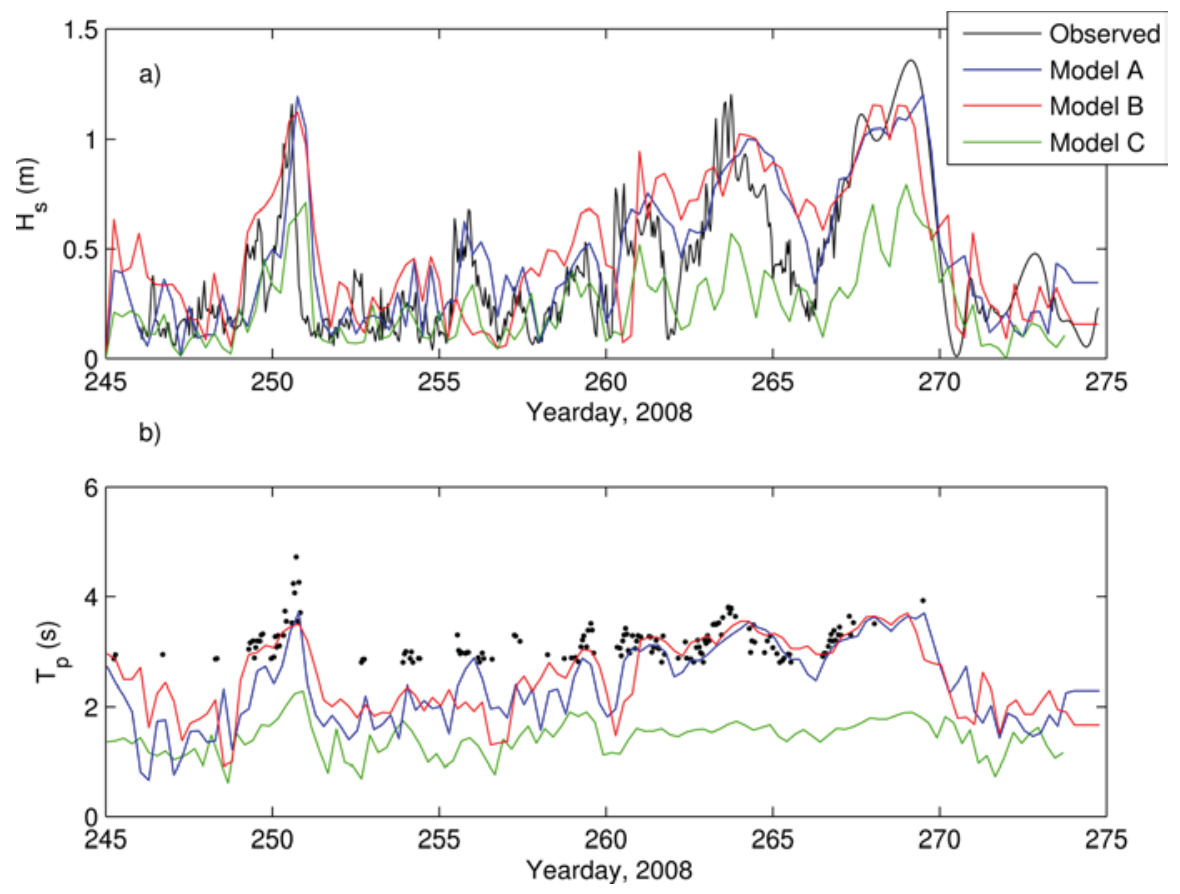

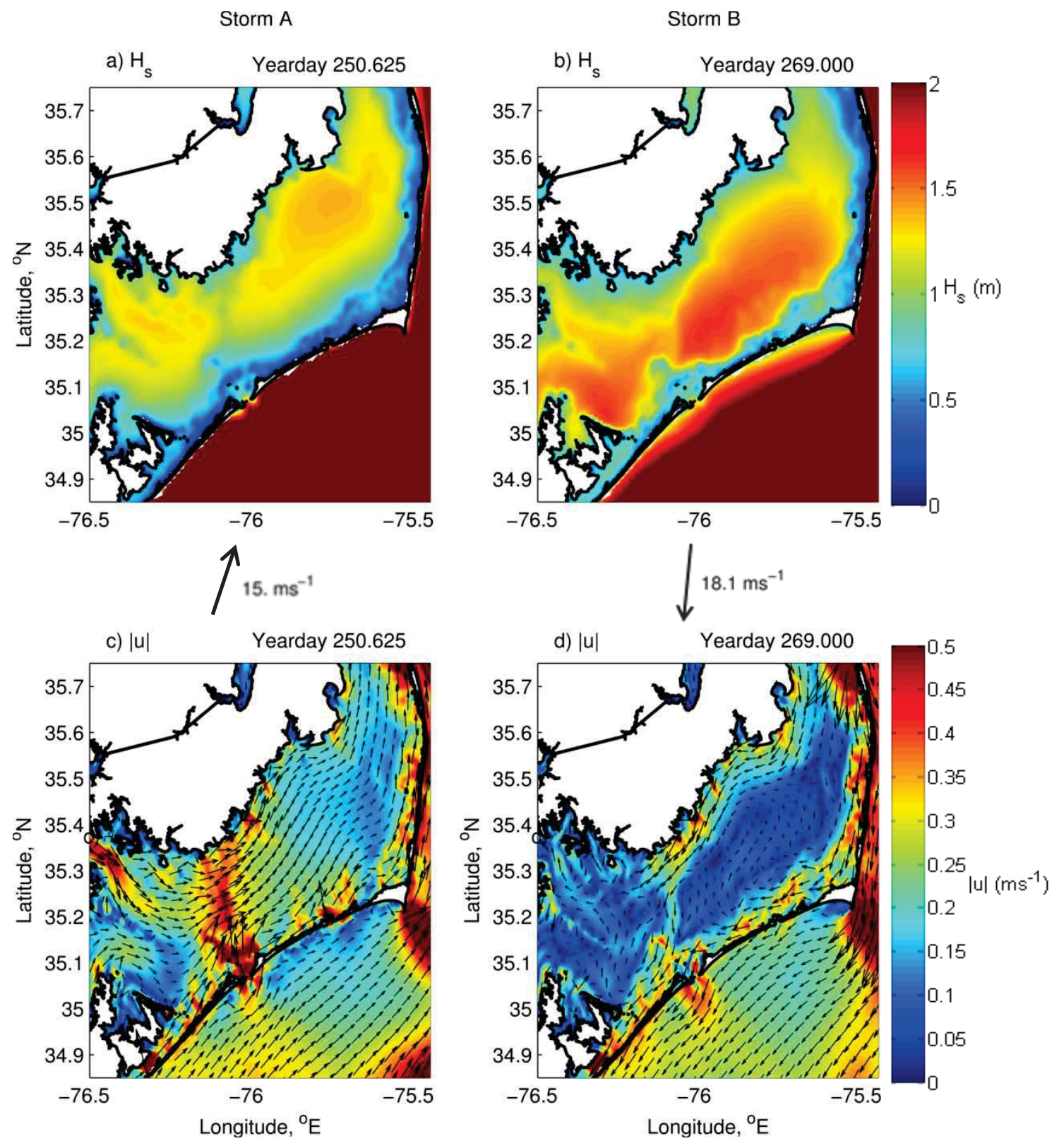

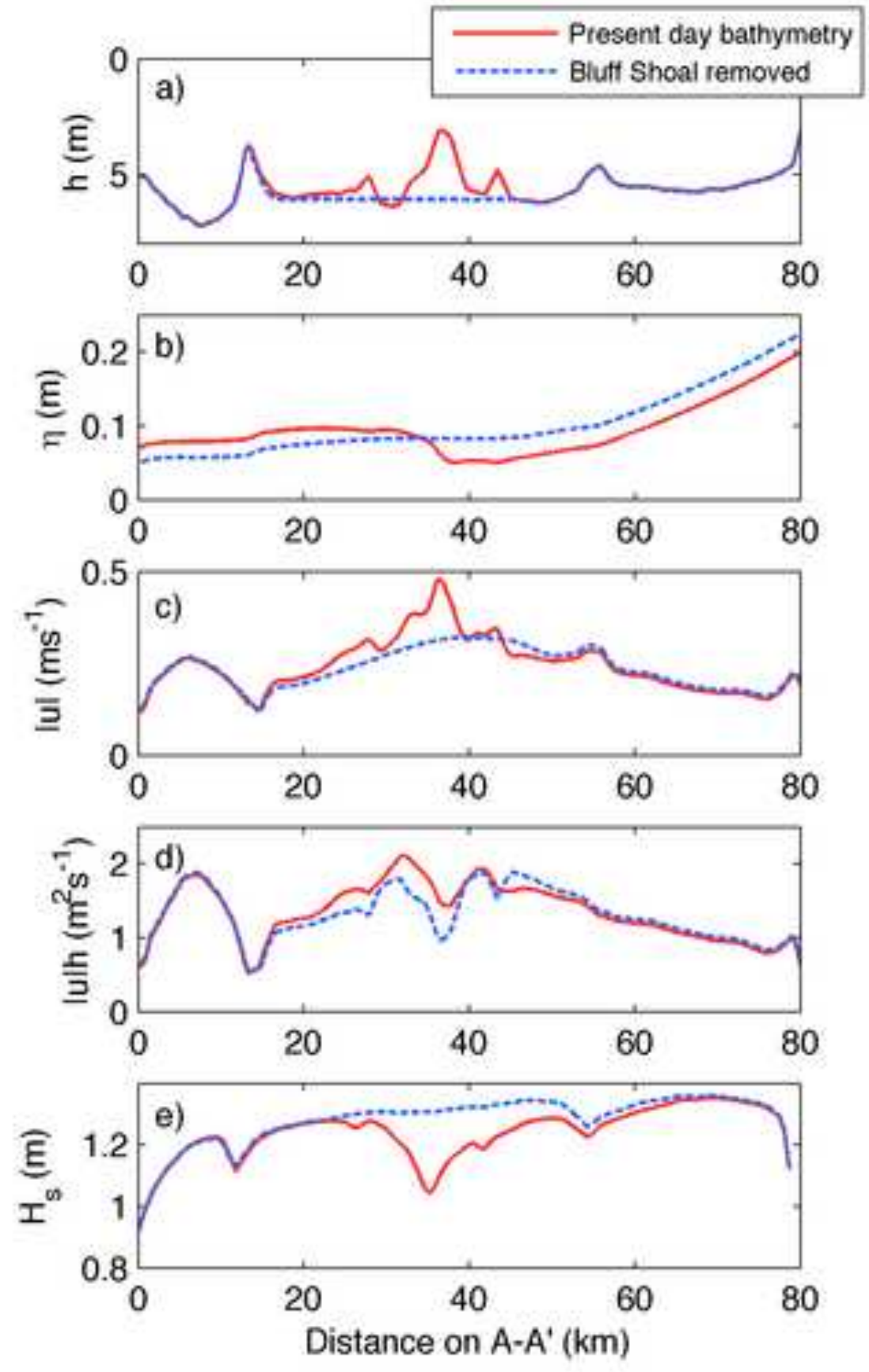

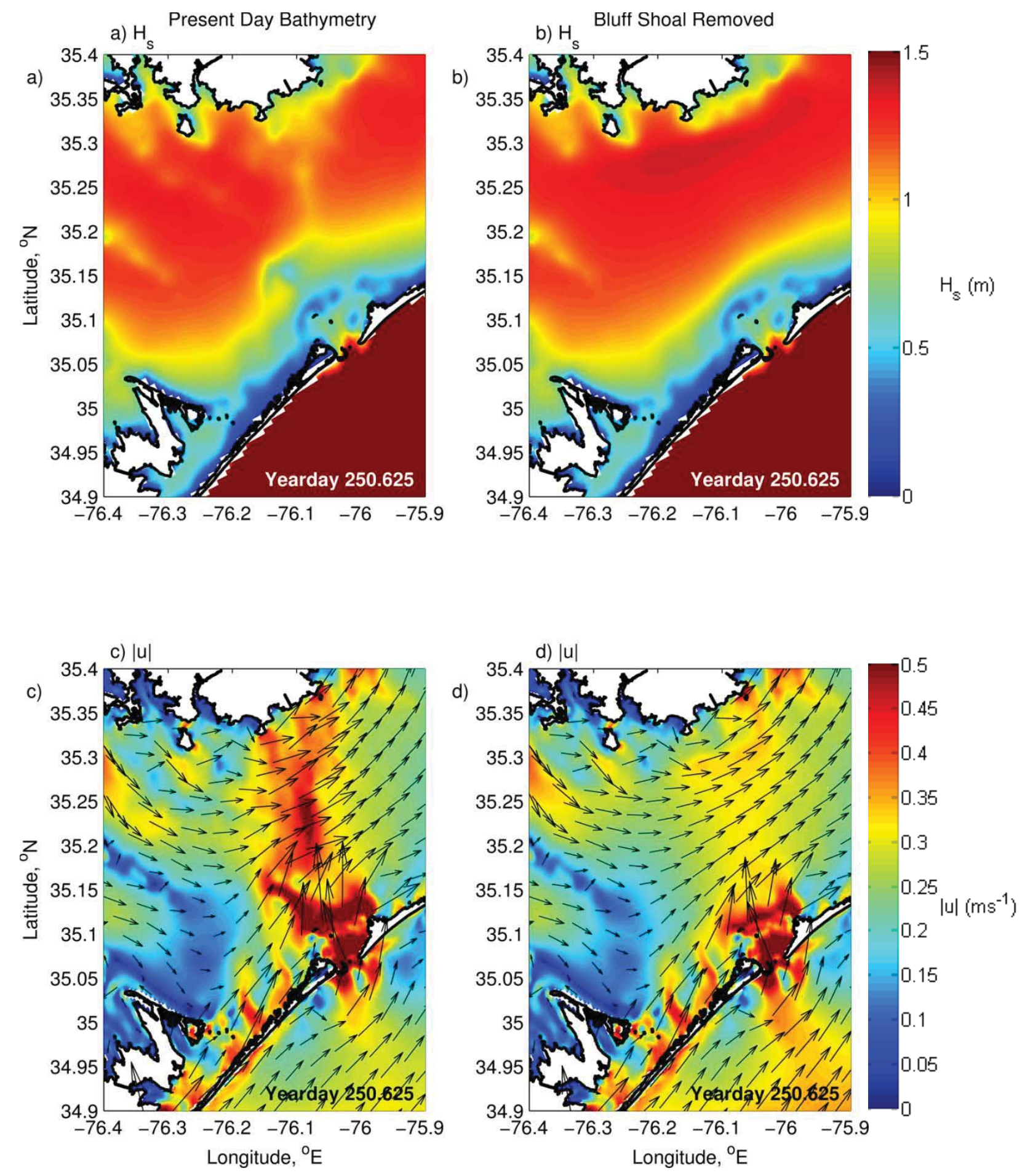